A. Kavousi and E. Raeisi - Estimation of groundwater mean residence time in unconfined karst aquifers using recession curves. Journal of Cave and Karst Studies, v. 77, no. 2, p. 108-119. DOI: 10.4311/2014ES0106

\title{
ESTIMATION OF GROUNDWATER MEAN RESIDENCE TIME IN UNCONFINED KARST AQUIFERS USING RECESSION CURVES
}

\author{
Alireza Kavousi and Ezzat Raeisi \\ Dept. of Earth Sciences, College of Sciences, Shiraz University,71454 Shiraz,Iran, kavousi@shirazu.ac.ir, e_raeisi@yahoo.com
}

\begin{abstract}
A new parsimonious method is proposed to estimate the mean residence time of groundwater emerging at any specific time during recession periods from karst springs. The method is applicable to unconfined karstic aquifers with no-flow boundaries. The only required data are numerous consecutive spring hydrographs involving a wide range of discharge from high to low flow and the relevant precipitation hyetographs. First, a master recession curve is constructed using the matching-strip method. Then, discharge components corresponding to the individual hydrographs at any desired time are estimated by extrapolation of recession curves based on the master curve. Residence times are also taken from the time elapsed since the events' centroids. Finally, the mean residence time is calculated by a discharge-weighted average. The proposed method was evaluated for the Sheshpeer Spring in Iran. There are 259 sinkholes in the catchment area of the Sheshpeer unconfined aquifer, and all the boundaries are physically no-flow. The mean residence time calculated by the proposed method was about one year longer than that of uranine dye tracer. The tracer mean time is representative of flowing water between the injection and emergence points, but the mean time by the proposed method is representative of all active circulating water throughout the entire aquifer. The proposed method is more appropriate, in practice, especially in groundwater recharge and contaminant vulnerability assessments, than isotopic methods, in cases where a small portion of water with exceptionally high residence time increases the mean. Moreover, isotopic methods are more expensive and not capable of directly determining the residence-time distribution.
\end{abstract}

\section{INTRODUCTION}

About 20 percent of the Earth's land surface is covered by carbonate-karst formations (White, 1988), and roughly 20 to 25 percent of the global population depends largely or entirely on karst groundwater (Ford and Williams, 2007). Carbonate karst comprises about 11 percent $\left(\sim 185,000 \mathrm{~km}^{2}\right)$ of Iran's land surface (Raeisi and Kowsar, $1997)$ and is one of the major fresh-water resources of the country.

Groundwater residence time is defined as the elapsed time for a water molecule to travel from the recharge area to the discharge zone of the aquifer (Kazemi et al., 2006; Bethke and Johnson, 2008). Water emerging from a karst spring is composed of billions of water molecules from different precipitation events. Karst aquifer recharge water flows rapidly through conduits and fractures and very slowly through the small pores and fissures where most of the recharged water may be stored for a long period, which is especially the case in Iran. Consequently, water with a wide range of residence times may be observed in the spring water. The residence-time distribution represents the distribution of different times, which is calculated by mathematical age-transport modeling (Kazemi et al., 2006). According to the age-mass concept (Goode, 1996), groundwater mean residence time (MRT) is the mass-weighted average residence time of all water emerging at a specific time. Knowledge of groundwater residence time is an invaluable tool for contaminant vulnerability assessment and evaluation of aquifer recharge rate during karst-water exploitation studies.

The MRTs of groundwater in karst aquifers have been estimated routinely by environmental and artificial tracers. Radioisotopes are the commonly used environmental tracer for this purpose. Considering the amount of a radioisotope in precipitation as input and in spring water as output, mathematical lumped-parameter (e.g. piston flow, dispersion, etc.) models have been used to estimate the MRT (e.g. Maloszewski, 1994).

Fluorescent dyes are the most practical and widely used artificial tracers in karst aquifers (Benischke et al., 2007). The mean transit time of dye can be approximated as the time difference between the injection and the centroid of the tracer-breakthrough curve (Benischke et al., 2007). For a sink-to-spring tracer test, the mean transit time represents the MRT for the part of the spring water that flows from the injection point during the conditions of the test.

Worthington (2007) reported that MRTs determined from environmental tracers are typically one hundred times longer than the mean transit times of artificial tracers in 
karstic aquifers. He concluded that the artificial tracers gave velocities and residence times for conduit flow, while environmental tracers gave the average flow velocities and MRTs of groundwater as a whole, including not only rapid flow through the conduits, but also the slow flow through the matrix and fractures, as well as the soil cover and epikarst.

Methods of determining mean residence time using either environmental or artificial tracers are expensive, and the procedure is usually cumbersome; and therefore, innovative approaches of MRT estimation using readily available data are of interest. For example, Vitvar et al. (2002) developed a method for estimation of baseflow MRT from an expression of soil contact time, using mean values of subsurface hydraulic conductivity and storage coefficient derived by hydrograph-recession characteristics. Also, Lalbat et al. (2007) proposed a simple hydrochemical indicator based on the concentrations of some major ions for estimating groundwater MRT in carbonate aquifers.

In this study, a method is proposed to determine the MRT of groundwater emerging during recession periods from a karst aquifer with a special boundary condition. The method uses the age-mass concept (Goode, 1996) to develop a new MRT-estimation method. The concept has been already used in the MRT calculations for simple mixing of hypothetical water components with known residence times (e.g., Kazemi et al., 2006, pp. 11-12; Bethke and Johnson, 2008, p. 131-132) and for age-transport modeling (e.g., Castro and Goblet, 2005; Doyon and Molson, 2012). Groundwater components with known residence times were detected using hydrograph recession and precipitation hyetograph data.

Recession curves have been utilized for different aims in karst hydrogeology, such as determination of hydraulic parameters (Atkinson, 1977; Baedke and Krothe, 2001), aquifer dynamic volume (Ford and Williams, 2007) and groundwater budget parameters (Raeisi, 2008), as well as hydrograph decomposition (Mangin, 1975; Atkinson, 1977).

The average hydraulic behavior of an aquifer from high to sustained, low flows can be also assessed using the master recession curve, which is a combination of various recession curves. In surface-water hydrology, constructing the master recession curve is a routine step in base-flow studies. However, the master curve has been also constructed and used for karst springs (e.g., Angelini and Dragoni, 1997; Desmarais and Rojstaczer, 2002; Posavec et al., 2006, 2010; Doctor, 2008; Malík and Vojtková, 2012; Gregor and Malík, 2012).

There are three principal methods to construct a master recession curve, including matching-strip (Snyder, 1939), tabulating (Johnson and Dils, 1956) and correlation (Langbein, 1938). Toebes and Strang (1964), Nathan and McMahon (1990), and Sujono et al. (2004) reviewed the methods, highlighting their advantages and disadvantages, and providing some examples as well. In this study, the matching-strip method was preferred, because of its simplicity, visibility of data irregularities, available automated computation tools, and wide usage in the karstaquifer context. However, other methods of constructing the master recession curve can be applied as well, if one prefers them because of better fitting statistics.

In the matching-strip method, recession curves are superimposed and adjusted horizontally until the main parts overlap; the mean line through the overlapping parts is the master recession curve (Toebes and Strang, 1964). Formerly, this method has been carried out manually by plotting of individual recessions on tracing papers. However, automated techniques have been developed in recent years (e.g., Lamb and Beven, 1997; Rutledge, 1998; Posavec et al., 2006, 2010; Gregor and Malík, 2012) that significantly facilitate the procedure.

Different mathematical functions based on empirical relationships and exact or approximate analytical solutions have been used to describe karst springs' recession curves (see Dewandel et al., 2003; Fiorillo, 2014). Semi-log plots of recession curves, i.e., $\log [$ discharge] versus time, for many karst springs show two or more linear segments with decreasing recession coefficients (e.g., Milanovic, 1976; White, 1988; Baedke and Krothe, 2001; Ford and Williams, 2007), suggesting piecewise exponential functions for the fitting. In this study, the master recession curve is also defined by a piecewise exponential function, composed of $m$ segments ending at times $t_{j}$ with $m$ recession coefficients $\alpha_{j}=1$ to $m$ and base discharges $Q_{0, j}=1$ to $m$.

$Q_{t}= \begin{cases}Q_{0(1)} e^{-\alpha_{1} t}, & t \leq t_{1}, Q_{t} \geq Q_{1} \\ Q_{0(2)} e^{-\alpha_{2} t} & t_{1}<t \leq t_{2}, Q_{1}>Q_{t} \geq Q_{2} \\ & \cdot \\ & \cdot \\ & \cdot \\ Q_{0(m-1)} e^{-\alpha_{m-1} t}, & t_{m-2}<t \leq t_{m-1}, Q_{m-2}>Q_{t} \geq Q_{m-1} \\ Q_{0(m)} e^{-\alpha_{m} t}, & t>t_{m-1}, Q_{t}<Q_{m-1}\end{cases}$

Equation (1) implies that the master recession curve is represented with $m$ straight lines with slopes of $-\alpha_{j}$ on a semi-log scale (see Figure $4 \mathrm{~b}$ for a simple example). Segmentation of recession curves has been justified by changes in flow regimes (Milanovic, 1976; Baedke and Krothe, 2001), catchment area, and effective porosity of the declining saturated zone (Bonacci, 1993; Fiorillo, 2011).

\section{Study Site}

To examine the proposed method of mean residence time estimation, the Sheshpeer Spring (Fig. 1) $80 \mathrm{~km}$ northwest of Shiraz in the Zagros Mountain Range, south-central Iran, was considered. The Zagros orogenic 


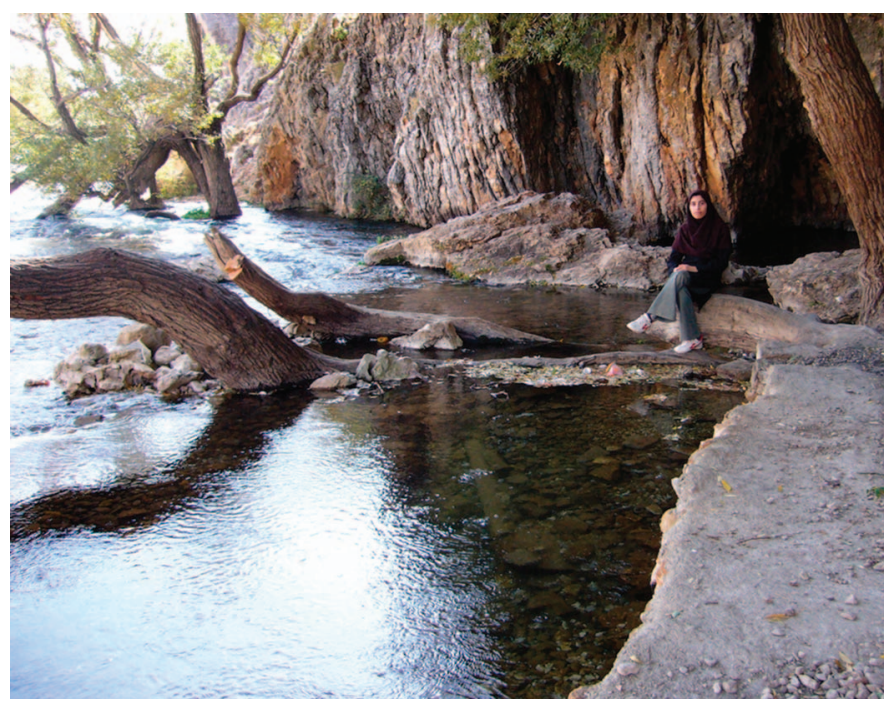

Figure 1. The Sheshpeer Spring, Zagros Mountains, Iran.

belt consists of three parallel northeast-southwest trending tectonic subdivisions, the Urumieh-Dokhtar Magmatic Assemblage, the Zagros Imbricate Zone, and the Zagros Fold-Thrust Belt (Alavi, 2007). Stratigraphy, lithology, and tectonic settings of the Zagros lithostratigraphic units are fairly well described in James and Wynd (1965), Falcon (1974), Stöcklin and Setudehnia (1971), and Alavi (1994, 2007). The Sheshpeer karst aquifer is situated at the border of the Zagros Fold-Thrust Belt and Imbricate Zone. Extensive hydrogeological researches have been carried out on the Sheshpeer aquifer (Pezeshkpour, 1991; Karami, 1993; Raeisi et al., 1993, 1999; Raeisi and Karami, 1996, 1997; Raeisi, 2008, 2010).

The Sheshpeer aquifer is composed of the calcareous Sarvak karstic formation (Albian-Turonian) in the northern flank of the Barm-Firooz and Gar anticlines and some portion of the southern flank of the Barm-Firooz anticline (Raeisi et al., 1993; Raeisi, 2008; Fig. 2). The anticlines are extended in the general direction of the Zagros Mountain Range and are connected by a saddle-shaped plunge. The exposed cores of the anticlines are mainly composed of the Sarvak Formation, underlain and overlain by impermeable shale and marl layers of the Kazhdomi (Albian-Cenemonian) and Pabdeh-Gurpi (Santonian-Oligocene) Formations, respectively. The most important tectonic feature is a major northwest-southwest trending thrust fault (Fig. 2). The northern flank of the anticlines has been brought up by tectonic forces, and the southern flank has been brecciated so that it's either completely removed or crops out as large rockslide blocks. Several normal and strike-slip faults are also present. The overall tectonic setting of the area has produced suitable conditions for extensive karstification (Raeisi and Karami, 1996, 1997; Raeisi, 2010).
The karst features of the study area are karrens, grikes, small caves, sinkholes, and springs. The most important karst feature is the presence of 259 sinkholes in the Gar and Barm-Firooz Mountains, lined up in a narrow zone on top of the northern flanks from the northern end of the catchment area to near the Sheshpeer Spring (Fig. 2). The sinkholes are primarily of the collapse type and coincide evidently with the direction of longitudinal faults. The biggest cave in the catchment area has a length of twenty meters and is located along a fracture (Raeisi, 2010). Out of twelve springs emerging from the Sarvak karstic formation in the Gar and Barm-Firooz anticlines, only Sheshpeer Spring, with a mean annual discharge of $3247 \mathrm{~L} \mathrm{~s}^{-1}$, is located on the northern flanks (Fig. 2). Berghan Spring is the largest spring in the southern flanks (Fig. 2) and has a mean annual discharge of $632 \mathrm{~L} \mathrm{~s}^{-1}$. The mean annual discharges for the other springs range from 1.41 to 68.34 $\mathrm{L} \mathrm{s}^{-1}$ (Raeisi and Karami, 1996).

All boundaries of the Sheshpeer aquifer are physically no-flow, and all recharged water only emerges via the Sheshpeer Spring (Pezeshkpour, 1991). Groundwater balance indicated a catchment area of about $81 \mathrm{~km}^{2}$ for the Sheshpeer Spring (Raeisi et al., 1993), which is in accordance with the area bounded by geological formations. The aquifer boundaries were drawn based on the following observations (Raeisi, 2008): (1) The northern flank of the Gar and Barm-Firooz anticlines have been brought up by tectonic stresses, such that the aquifers of the northern and southern flanks have been disconnected by the underlying impermeable Khazdumi Formation that crops out in some parts of the anticline core (Fig. 2). Tracer tests have confirmed this hydrogeological disconnection. (2) The northwest and northeast sides of the catchment area are bounded by the impermeable PabdehGurpi Formations. Groundwater flow through the Sarvak Formation under these formations is not possible, because karstification usually does not occur under an 800-m thick layer of the Pabdeh-Gurpi Formations, there are no outcrops of the Sarvak Formation in adjacent parallel anticlines, and tracer tests confirmed the hydrogeological disconnection with the springs of the adjacent anticlines. (3) Sinkholes are only located in the catchment area of the Sheshpeer Spring, and the dye tracer injected in a sinkhole $18 \mathrm{~km}$ away (Fig. 2) only emerged from this spring, as described below.

In order to characterize the function of the Gar and Barm-Firooz karst systems, a tracer test was performed by Raeisi et al. (1999) during the recession period of the year 1992. Sodium fluorescein (uranine) dye was injected into a sinkhole in the Barm-Firooz Mountain, $18 \mathrm{~km}$ away from the Sheshpeer Spring (Fig. 2). The inflow of snowmelt to the sinkhole was about $150 \mathrm{~L} \mathrm{~s}^{-1}$ at the time of injection. The dye was detected only in the Sheshpeer Spring, and most of it was recovered before the recession was interrupted (Fig. 3). The first appearance, peak concentration, and centroid times of the tracer breakthrough curve 


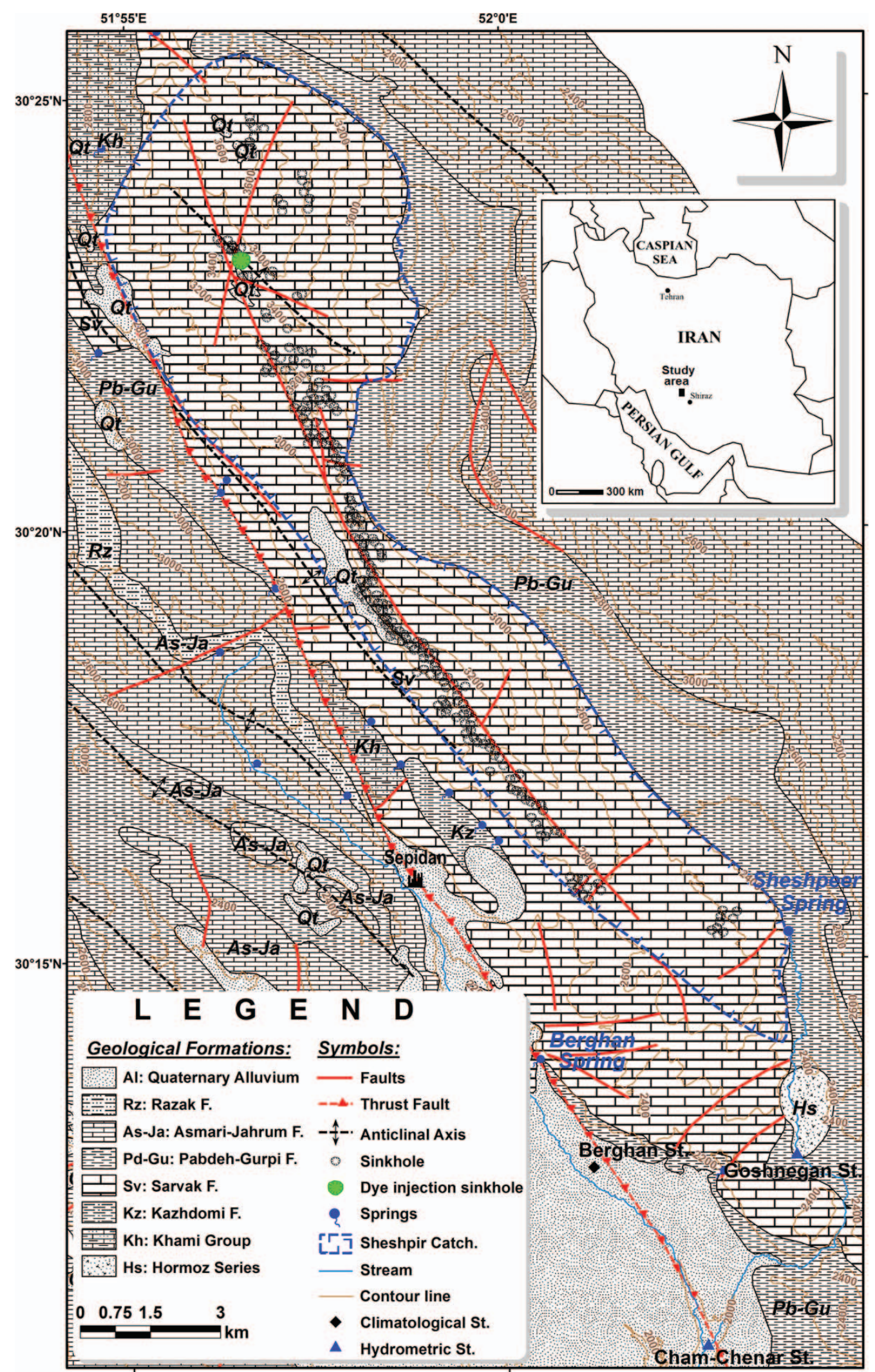

Figure 2. Hydrogeological map of the study area. The recharge area of Sheshpeer Spring is outlined in blue. Besides gauging information from Sheshpeer Spring, stage data from the Goshnegan and Cham-Chenar stations (shown as blue triangles) and precipitation data from Berghan station (shown as a black rhombus) were used in the calculations. 


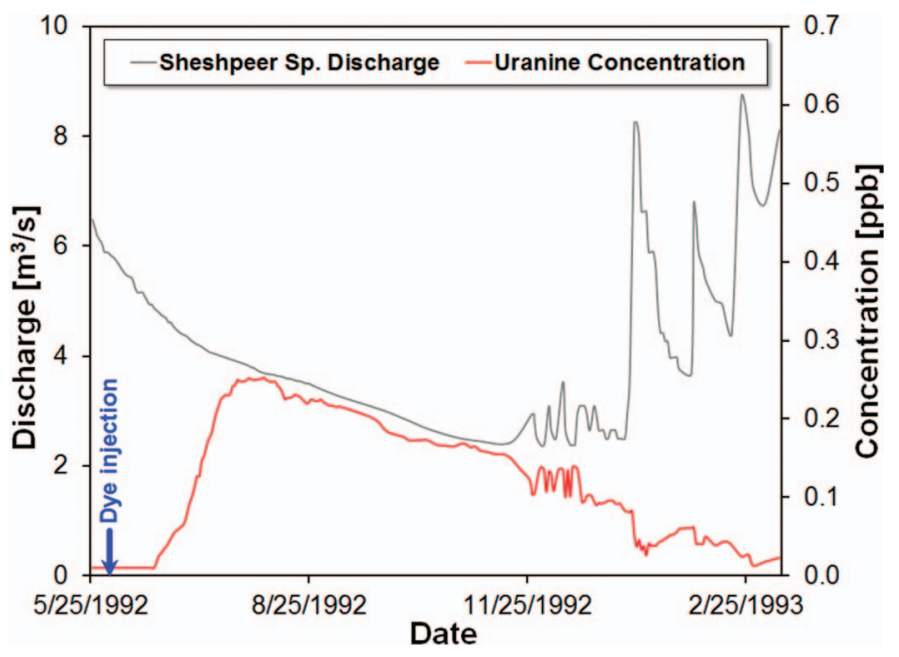

Figure 3. Tracer breakthrough curve for a dye trace during the 1992 recession period, plotted along with the spring discharge.

were estimated to be about 19, 64, and 115 days, respectively. Accordingly, the maximum, dominant, and mean linear flow velocities were calculated to be about 40 , 12 and $7 \mathrm{~m} \mathrm{~h}^{-1}$, respectively; which are within the range of conduit flow, as is expected from a sink-to-spring tracer test.

\section{METHODS}

The proposed method estimates the mean residence time of groundwater leaving via springs or underground outflows to neighboring aquifers during recession period of an unconfined karst aquifer with no-flow boundaries. The no-flow boundaries can consist of impermeable layers or groundwater divides.

Recharge water might be stored for a long period within the aquifer, gradually discharging through the spring, hence the measured hydrograph is regarded here as a composite hydrograph that is a combination of several consecutive individual hydrographs caused by numerous previous precipitation events. Figure 4 a shows a hypothetical spring composite hydrograph that is decomposed to its individuals by graphical extrapolation of recession curves.

At any specific time $(T)$ during the recessions, the measured discharge is the summation of discharge components $\left(\Delta Q_{(i)}\right)$ that are the contributions of the individual extrapolated hydrographs to time $T$. The discharge component corresponding to the fifth precipitation event at time $T, \Delta Q_{(5)}$, is indicated in Figure 4a. The residence time for each discharge component at the time, $t R_{(i)}$, is defined as the time elapsed since the centroid of precipitation event $i$. The residence times for the different discharge components at time $T$ are indicated in Figure 4a.

Once the discharge components and residence times corresponded to the all individual extrapolated hydro- graphs are calculated for time $T$, the mean residence time $\left(\overline{t_{R}}\right)$ at the time is calculated as the discharge-weighted average residence times,

$$
\bar{t}_{R}=\frac{1}{Q_{T}} \sum_{i=1}^{n}\left(t_{R(i)} \times \Delta Q_{(i)}\right)
$$

where $Q_{T}$ is the measured total spring discharge at time $T$ on the composite hydrograph, equal to the sum of the discharge components, and $i$ from 1 to $n$ is the number of a preceding precipitation event, from oldest to more recent.

Equation 2 implies that the estimated MRT at time $T$ is controlled by the total spring discharge $Q_{T}$, the residence times, and the discharge components. The total spring discharge is directly measured; high accuracy in discharge measurement can be achieved using high-tech devices. Residence times need the precipitations' centroids to be determined and can be estimated fairly well using highfrequency (e.g. daily) precipitation data. Therefore, the most uncertain parameters in the MRT calculation are the discharge components, which are based on the recessioncurve extrapolations. Discharge components are estimated by graphical extrapolation of recessions in Fig. 4a. However, this method is based on subjective judgment and does not consider the characteristics of the aquifer. The recessional behavior depends on the lithology, porosity, degree of karstification, and type of flow regime, as well as the spatial and temporal characteristics of the precipitation.

A master recession curve is considered as the most probable recession scenario under a given situation (Nathan and McMahon, 1990), and it is constructed using all prior recorded recessions, from high to low flows. Therefore, it is an index of the particular aquifer's recessional behavior and is used here to extrapolate the recession curves, decompose the composite hydrograph, and estimate the discharge components.

In this study, the matching-strip method was applied to construct a segmented exponential master recession curve. Figure $4 \mathrm{~b}$ presents a typical curve composed of three exponential segments with decreasing recession coefficients.

Because we are only interested in the recessions, the rising limbs are ignored in assembling the composite curves in Figure 4c. Since the figure is a semi-log plot, even the measured parts of the individual recession curves are approximated as segmented straight lines. To extrapolate from the last measured discharge on each recession curve, such as $Q_{e(5)}$ in Figure 4, the portion of the master curve below that value is shifted and appended, extending to time $T$. The extrapolated straight line segments are shown dashed in Figure 4c.

After extrapolation of all the recession curves to time $T$, the discharge due to each individual event is the difference between successive curves. The hatched area on Figure 4c 

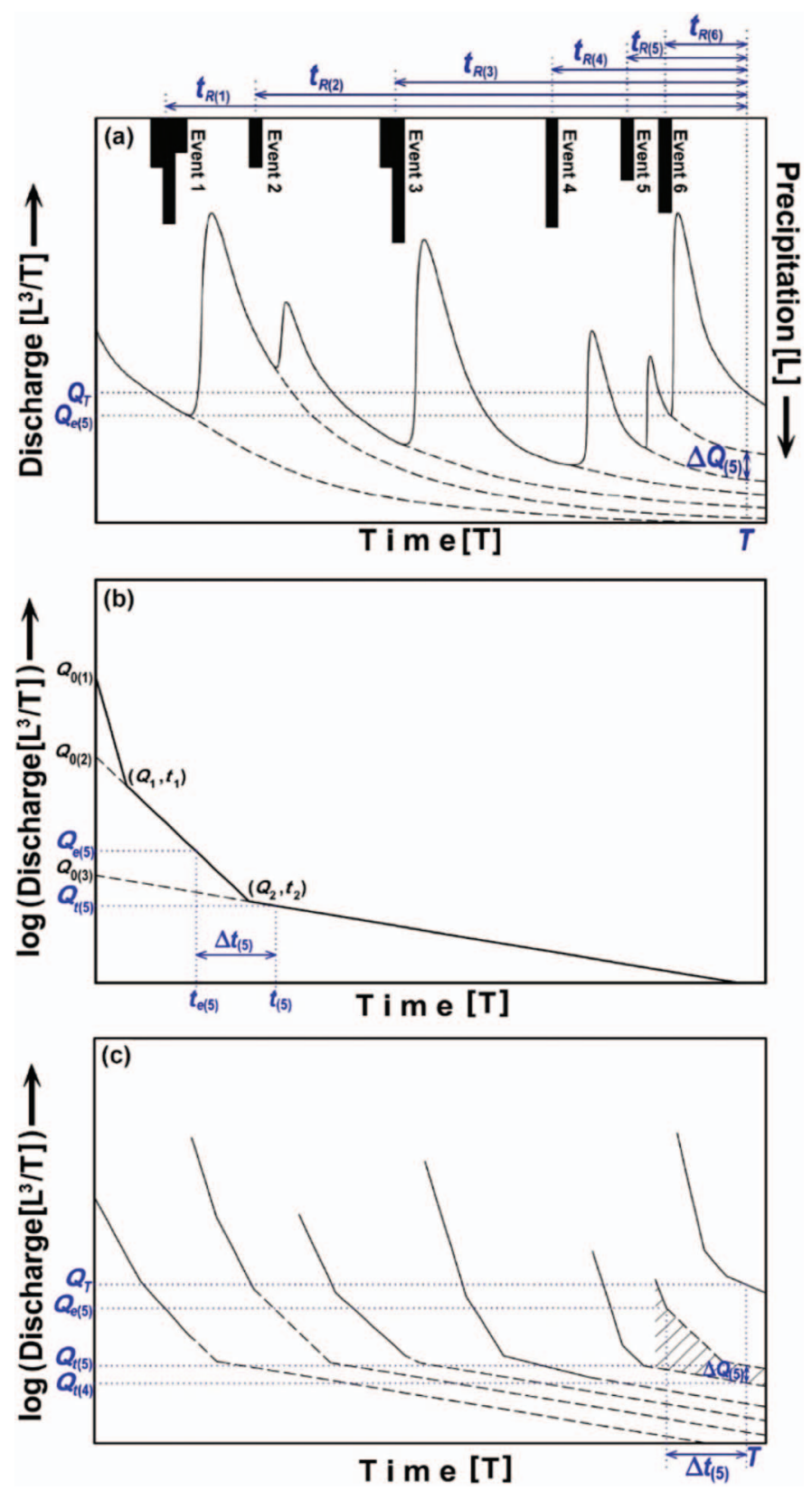

Figure 4. Diagrams showing the principle of the method, using hypothetical discharge curves and precipitation events. At time $T$ during the recession following rainfall event 6 , the total flow $Q_{T}$ is decomposed into components due to several recent events, such as $\Delta Q_{(5)}$ due to event 5 , by extrapolating the recession curves of the various events using a master recession curve approximated by a series of exponential decline segments. Part (a) shows the assumed data and the precipitation events on a linear scale. Extrapolated recession curves are graphically appended. Part (b) shows segments of the master recession curve, which become straight lines on the semi-log plot; the notation is that of Equation 1. $Q_{e(5)}$ is the flow at the end of the recession following event 5 at master-recession-curve equivalent time $t_{e(5)}$, and $Q_{t(5)}$ is the inferred flow of the extrapolated event 5 recession at time $T$, represents the volume of discharged water due to the fifth precipitation event, since the hydrograph peak. At time $T$, the discharge component from the fifth precipitation event, $\Delta Q_{(5)}$, is shown in Figure $4 \mathrm{c}$ as the difference between the extrapolated discharges $Q_{t(5)}$ and $Q_{t(4)}$.

The residence time corresponding to each discharge component at time $T$, i.e. $t_{R(i)}$, is calculated as the time difference between the relevant precipitation centroid and time $T$, as previously described. Finally, the mean residence time at time $T$ is estimated using Equation 2.

\section{RESUlts AND Discussion}

The hydrograph data of the Sheshpeer Spring were only measured for three hydrological years from 1990 to 1992 and contain five hydrograph recessions. These hydrograph data are not enough to apply the proposed method. Therefore, a multiple time series regression model (Phillips and Durlauf, 1986) was applied to reconstruct spring discharge from 1979 to 1989 , using daily data of two hydrometric stations and one meteorological station, for use in addition to the measured Sheshpeer Spring hydrographs (Fig. 5).

Daily precipitation at the Berghan meteorological station (Fig. 2) is available for almost 51 years. The Goshnegan and Cham-Chenar hydrometric stations (Fig. 2), with 30 and 20 years of daily discharge data, are located about five and ten kilometers downstream of the Sheshpeer Spring, respectively. Goshnegan is the best hydrometric station to monitor the Sheshpeer Spring discharge other than a gage at the spring itself. Flood water from a small area of Pabdeh-Gurpi formations reaches the station during high flows, but there is no inflow during dry seasons. Discharge at the Goshnegan station was measured daily from 1979 to 1986 , but the station was ungauged from 1987 to 1992.

The multiple time series regression model (Phillips and Durlauf, 1986) was used to find the relationship between the measured seven years of daily discharge data from Goshnegan Station (1979 to 1986) with the daily discharge data from the Cham-Chenar Station and the daily precipitation at the Berghan station. The adjusted $R^{2}$ was 0.98 , which is very close to 1 , showing the accuracy available for reconstructing the missing six years (1987 to 1992) of daily discharge at the Goshnegan Station using that regression model.

\footnotetext{
$\leftarrow$

which is $\Delta t_{(5)}$ after the end of the event 5 recession (not be confused with $t_{R(5)}$ in part (a), which is the time between the centroid of event 5 and $T$ ). Part (c) is like part (a) except that the extrapolations are based on the master recession curve, and the recession parts of the hypothetical discharge curves, together with their extrapolations, are only shown. Notice that the plot is on semi-log scale.
} 


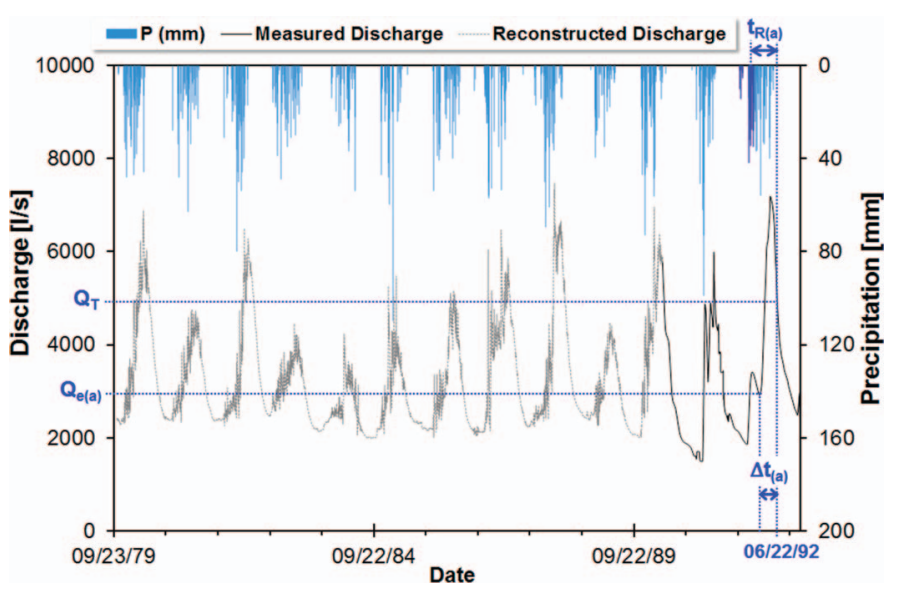

Figure 5. Measured discharge at Sheshpeer Spring for 1990-1992 (solid line) and discharge inferred from other data for 1979-1989 (dotted line). Notations are the same as those in Figure 4, with (a) replacing (5) for the first event of the year 1992. June 22, 1992, is the date for which the calculations are described in detail in the text. Also shown is the rainfall record for the period, on an inverted scale.

Daily Sheshpeer Spring discharge from 1979 through 1989 were subsequently reconstructed by the same procedure, using the daily precipitation of Berghan station and discharge at the Cham-Chenar and Goshnegan stations and Sheshpeer Spring. The adjusted $R^{2}$ was 0.89 , which is again close to 1 . The reconstructed data for Sheshpeer Spring are shown in Figure 5, along with the later measured data.

Master recession curve (Fig. 6 and Table 1) was manually constructed using Hydro-Office RC 4.0 Module (Gregor and Malík, 2012), using both measured and reconstructed Sheshpeer discharge data from Figure 5. The curve was fitted by five exponential segments, shown as straight line segments on the semi-log plot in Figure 6, with recession coefficients, time ranges, and discharge ranges for each segment given in Table 1. A good match between the measured discharges for 1990-1992 and the master recession curve indicates the accuracy of data reconstruction.

Table 2 presents the recession coefficients, discharge ranges, and durations of the exponential segment of the

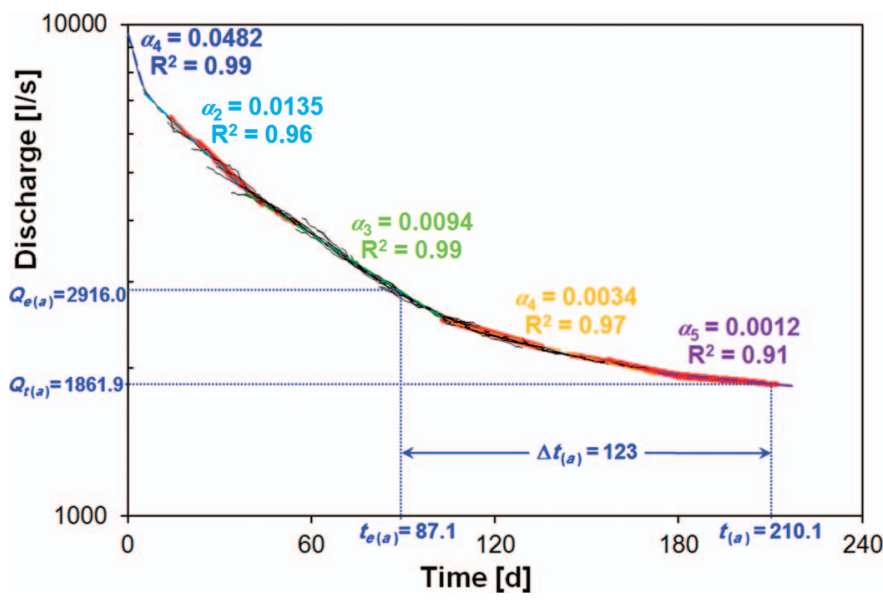

Figure 6. The master recession curve for Sheshpeer Spring on a semi-log scale. The master curve shown by the thin black line has been broken into five segments that are straight lines on that scale. The recession coefficients for each segment are indicated. Dotted lines show how $Q_{e(a)}$, the final measured discharge for the event $(a)$, and the time between that measurement and $\Delta_{t(\mathrm{a})}$, the time for which calculations are being made, here 123 days, are used to infer from the master curve $Q_{t(\mathrm{a})}$, the flow due to event $(a)$ at the later time.

measured recession curves for the years 1990 to 1992 (Pezeshkpour, 1991; Karami, 1993; Raeisi et al., 1993), compared to the corresponding data from the constructed master recession curve. The curve's recession coefficients $\alpha_{1}$ to $\alpha_{5}$ were $0.0482,0.0135,0.0094,0.0034$ and $0.0012 \mathrm{~d}^{-1}$, respectively. Those corresponding to the lower discharge ranges (i.e., $\alpha_{2}, \alpha_{3}, \alpha_{4}$, and especially $\alpha_{5}$ ), which have significant effects on the mean residence time estimation, are within the range of recession coefficients of the measured recession curves.

As an example of the proposed method, the mean residence time is calculated for a specific time, June 22, 1992, during the second recession of the year 1992 (Fig. 5). Fig. 7 presents the measured recession curves of the Sheshpeer Spring and their extrapolations based on the master recession curve in Figure 6. Detailed calculations of discharge component for only the first recession of year 1992, using the subscript $a$, and the corresponding residence time are presented here.

Table 1. Sheshpeer spring master recession curve shown as five exponential straight-line segments on the semi-log plot in Figure 6, with time ranges, and discharge ranges for each segment with respect to $Q_{t}$.

\begin{tabular}{lcc}
\hline Recession Segments & Time Ranges, d & Discharge Ranges, $\mathrm{L} \mathrm{s}^{-1}$ \\
\hline $9469.5 e^{-0.0482 t}$ & $t \leq 5.87$ & $Q_{t} \geq 7137.2$ \\
$7725.2 e^{-0.0135 t}$ & $5.87<t \leq 38.26$ & $7132.2>Q_{t} \geq 4612.3$ \\
$6607.8 e^{-0.0094 t}$ & $38.26<t \leq 105.24$ & $4612.3>Q_{t} \geq 2457.9$ \\
$3529.7 e^{-0.0034 t}$ & $105.24<t \leq 172.31$ & $2457.9>Q_{t} \geq 1951.6$ \\
$2419.0 e^{-0.0012 t}$ & $t>172.31$ & $Q_{t}<1951.6$ \\
\hline
\end{tabular}




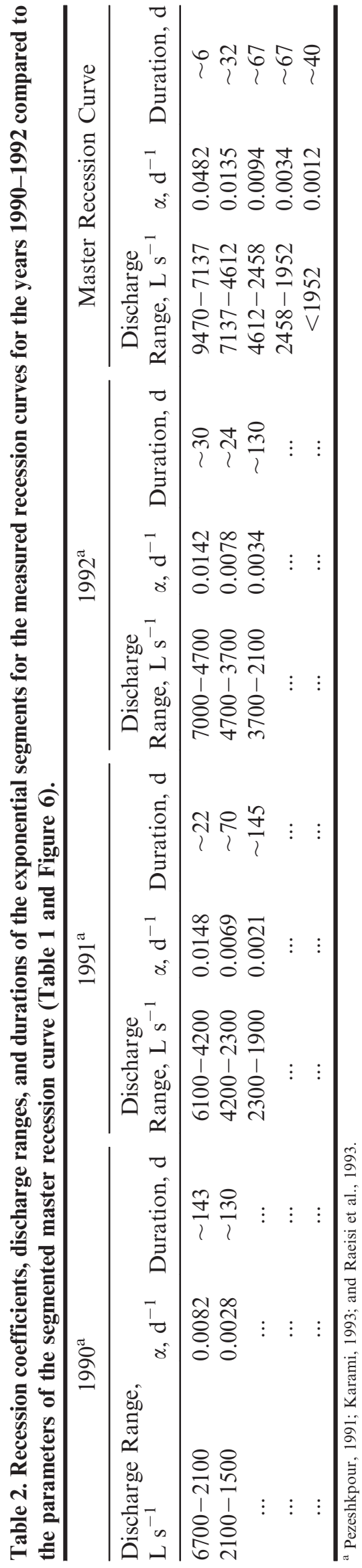

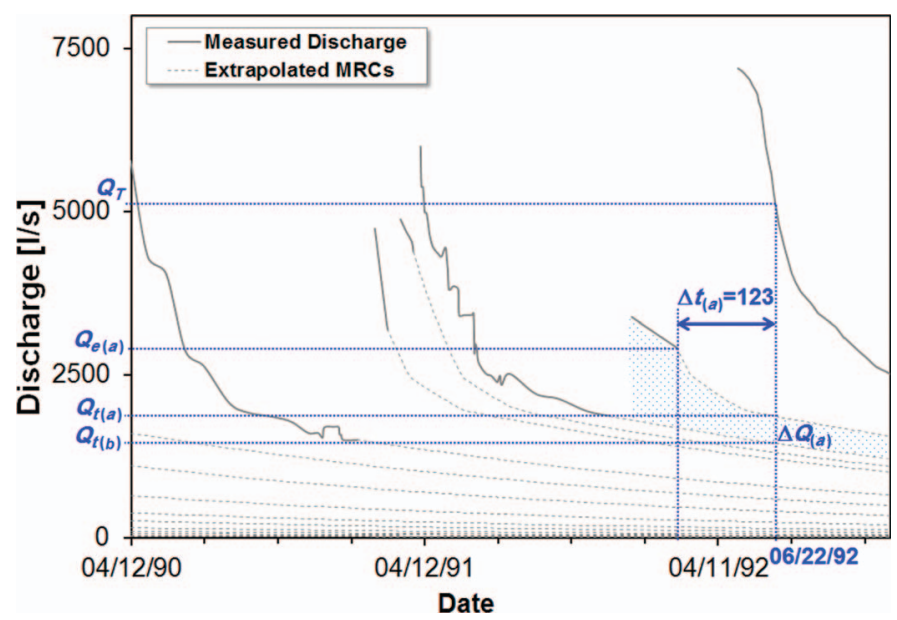

Figure 7. Detail from the last years of Figure 5, showing the application of the method in Figure 6 to the discharge from the recession preceding the one occurring during the target date of June 22, 1992. The stippled area shows the contribution from that event to the total flow.

The discharge at the end of hydrograph recession $a$, on February 20, 1992, was equal to $2916.0 \mathrm{~L} \mathrm{~s}^{-1}$ (Fig. 5 and 7). Therefore, the master-recession-curve equivalent time of $Q_{e(a)}$, i.e. $t_{e(a)}$, was calculated to be about 87.1 days using the master-recession-curve (Table 2 and Fig. 6); and the duration of extrapolation, $\Delta t_{(a)}$, was 123 days (Fig. 5 and 7). $t_{(a)}$, the master-curve equivalent time of the recession hydrograph $a$ at the MRT estimation time, is the sum of $t_{e(a)}$ and $\Delta t_{(a)}$, and was calculated to be about 210.1 days (Fig. 6). Thus $Q_{t(a)}$ was calculated to be $1861.9 \mathrm{~L} \mathrm{~s}^{-1}$ using master recession curve (Table 2 and Fig. 6). The discharge of the previous individual hydrograph, the third recession hydrograph of the year 1991, namely $b$, was calculated in the same way to be about $1445.6 \mathrm{~L} \mathrm{~s}^{-1}$ on June 22, 1992, and $\Delta Q_{(a)}$ was calculated to be about $416.3 \mathrm{~L} \mathrm{~s}^{-1}$ (Fig. 7). Values of $\Delta Q_{(i)}$ for all other individual hydrographs that made a contribution to the spring flow on June 22, 1992, were calculated using the above procedure. The precipitation centroid corresponding to hydrograph $a$ occurred on December 22, 1991; and $t_{R(a)}$ was about 182.5 days (Fig. 5). Values of $t_{R(\mathrm{i})}$ for all other individual hydrographs were also calculated.

Our new method directly determines the residence-time distribution without using any tracer data. Figure 8 shows the residence-time distribution, as percentage of discharge component versus residence time, for June 22, 1992.

The oldest individual hydrograph used in the mean residence time calculation was from the year 1979. The oldest discharge component i.e. $\Delta Q_{(1)}$, on June 22 , 1992, contributed about $0.13 \%$. This is shown as DC- 1 in Figure 8. There were no hydrographs before 1979; $\Delta Q_{(1)}$ was the summation of discharge components from 1979 and all earlier years, and it was necessary to estimate what residence time should be used for that component in 


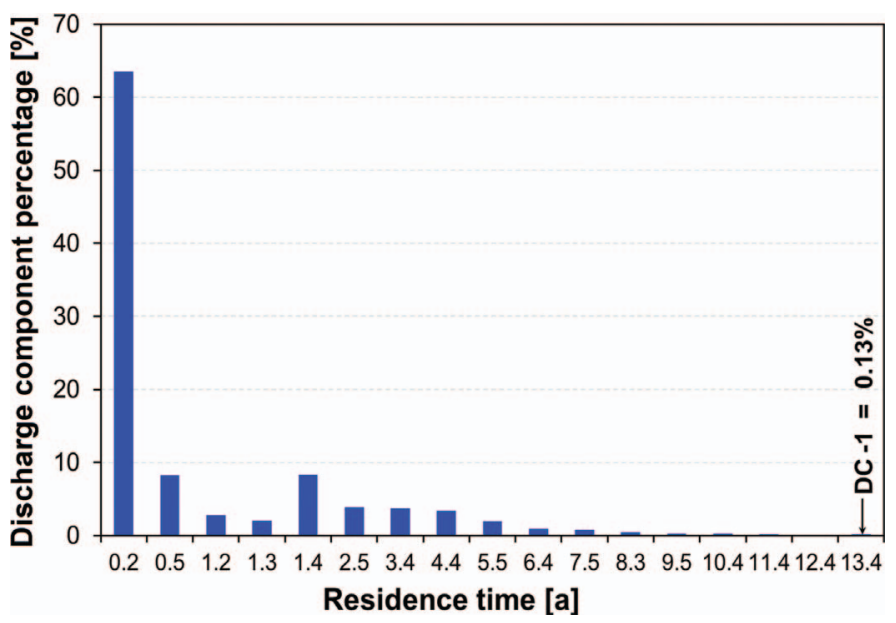

Figure 8. Residence-time distribution on June 22, 1992, based on the decomposing of total discharge on June 22, 1992, into discharge components by the method described in the text and shown in Figure 7. The percentage contribution of each prior recharge event is plotted. Note that the horizontal axis of residence-time (years) is not linear, but simply contains a point for each $t_{R(i)}$, the time since the contributing event, as labeled. DC-1, nominally for 1979, includes all water that old or older.

calculating the mean. As the first alternative, the starting time of $t_{R(1)}$ was considered as the precipitation centroid of 1979 , and other mean residence times for that component were assumed to be $100,500,1000$, or 10000 years. The assumption of a long residence time is reasonable due to the small amount of water that might take a long time to join the main karst conduit because it has been retained in very small pores and fissures of the karst aquifer. Assuming the first alternative the mean residence time of the discharge on June 22, 1992, is estimated to be about 1.1 years using Equation 2. The means for all alternatives are presented in Table 3. The MRT would not change significantly even if the mean age of the oldest component $t_{R(1)}$ was taken to be 100 years. However, if it was increased

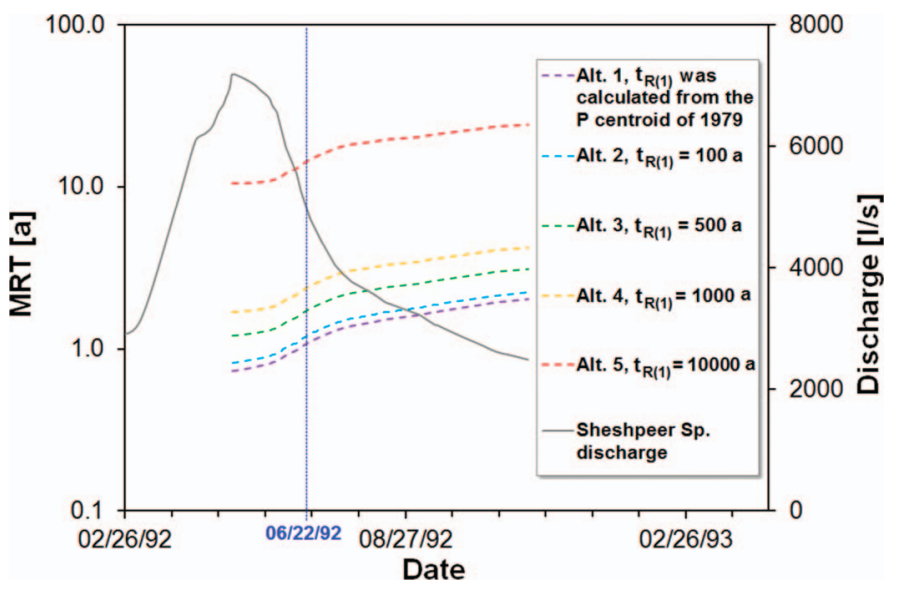

Figure 9. The colored curves show the mean residence time computed for the outflow from Sheshpeer Spring at different times during the second recession of 1992 for different assumptions about the mean age in years of the earliest discharge component. The vertical blue line is the date of the computation discussed in most detail, and its intersections with the colored curves show the data in the left half of Table 3. The vertical extents of the colored curves give the data for the right half of Table 3 . Note that the residencetime data are plotted on a logarithmic scale. The total discharge curve for the spring is shown for comparison.

to considerably more than 100 years, the MRT would significantly increase.

The MRTs were also calculated in the same way for different dates, other than June 22, during the second recession period of the year 1992 (Fig. 9). The MRTs increased as the recession proceeded, due to a decrease in the most recent component and the increased residence times. Table 3 shows the minimum, average, and maximum MRTs over the range of end-point dates during the recession for all alternative values of the oldest age. The average MRTs in the table are the mean age of all groundwater emerging from the spring during the entire recession.

Table 3. The approximate calculated mean residence times for June 22, 1992, and throughout the duration of the recession, for various assumed mean yearly ages for the oldest discharge component.

MRT during the second

recession period of 1992 , a

\begin{tabular}{|c|c|c|c|c|c|}
\hline Alternative & Assumed $t_{R(1)}$, a & MRT June 22, 1992, a & Minimum & Average & Maximum \\
\hline 1 & $13.4^{\mathrm{a}}$ & 1.1 & 0.7 & 1.4 & 2.0 \\
\hline 2 & 100 & 1.2 & 0.8 & 1.5 & 2.2 \\
\hline 3 & 500 & 1.7 & 1.2 & 2.1 & 3.1 \\
\hline 4 & 1000 & 2.4 & 1.7 & 2.9 & 4.2 \\
\hline 5 & 10000 & 14.1 & 10.5 & 17.4 & 24.2 \\
\hline
\end{tabular}

${ }^{a}$ Calculated from the precipitation centroid of 1979, and was equal to 4906.1 days (ca. 13.4 years), for June 22, 1992 
Recalculation of MRTs for different dates during the recession period also confirms that the MRT would significantly increase if the oldest water was assumed to be considerably older than 100 years. The percentage contribution of the oldest discharge component during the recession period was also calculated over that range of end dates, and its minimum, average and maximum were 0.10 , 0.16 and 0.22 percent, respectively. Therefore, it can be concluded that the proposed method estimates, at least, the residence times of 99.78 percent of the total spring discharge. The precision of the MRT would be improved if the number of hydrographs increased, therefore, reducing the amount of discharge of unknown age. The portion of spring-water with uncertain residence times in our study is a very small amount and it doesn't have a significant impact for most practical applications such as groundwater exploitation studies.

Since a mean age of more than 100 years is very unlikely for the oldest discharge component, the mean residence time of Sheshpeer Spring discharge during the second recession period of the year 1992 most likely ranged from 0.7 to 2.2 years (see Table 3 ).

The mean transit time of uranine tracer, which is approximated as the time difference between the injection and the centroid of the breakthrough curve, was calculated to be about 112 days for the Sheshpeer Spring during the 1992 recession (Fig. 3). The average of the MRTs calculated by our method from the dye injection date to the end of recession is estimated to be about 1.4 or 1.5 years. The dye's mean transit time of 112 days is smaller than our calculated value because the dye was directly injected to the conduit system via a sinkhole with inflow rate of $150 \mathrm{~L} \mathrm{~s}^{-1}$, and it is representative for a special groundwater flow path between the injection point and Sheshpeer Spring, whereas our calculation applies to the entire aquifer, including water paths through the aquifer matrix and conduits, as well as the soil, epikarst, and vadose zones.

A qualitative comparison highlights some superiorities of the proposed method over the conventional isotopic methods: (a) The proposed method is very parsimonious, such that the only required data are the spring hydrograph and the relevant precipitation hyetograph, which have been frequently recorded for many karst springs even in developing countries. (b) The mean residence time and the residence-time distribution at any specific time during a hydrograph recession can be determined. (c) The proposed method directly estimates the residence-time distribution of spring-water; previously the only method to determine this was mathematical modeling based on the solution of age-transport equations (Kazemi et al., 2006). (d) In some cases, a very small portion of water with exceptionally high residence time can dramatically increase the mean obtained by isotopic methods. Those methods are correct in principle, but the estimated MRT is misleading, as it is not representative of the bulk of the emerging water.
Therefore, the proposed method is more practical for all cases in which the residence time of a small portion of the water is unimportant, such as groundwater-recharge estimation and contaminant-vulnerability assessment.

\section{Conclusions}

A new method is proposed to estimate the mean residence time of water emerging from karst springs during recession periods. The method is based on a dischargeweighted average formula (Eq. 2), which needs the size of various discharge components and their residence times relative to the target time. The discharge components can be estimated by decomposition of the measured composite hydrograph into the individual hydrographs from preceeding precipitation events using a master recession curve, and the residence time can be taken as the time elapsed since the event's centroid. The proposed method of MRT estimation was successfully applied to the Sheshpeer Spring. The number of available previous hydrographs was limited for this case study. The greater the number of recession hydrographs over a range from high to low flows available, the greater the reliability of the result.

The proposed method is capable of estimating the MRT for unconfined karstic aquifers with no-flow boundaries. This hydrogeological setting is typical for the Zagros region anticlines, where carbonate karstic formations are enclosed by thick, impermeable non-karstic formations. The method is most practical in regions with relatively long gaps between precipitation events, so that the individual hydrographs corresponding to each event are easily identifiable. This situation is frequently observed in arid or semi-arid karst regions, like most parts of Iran. The method is not applicable if old water emerges from the spring due to piston flow after the beginning of recessions, and is applicable after the time of minimum electrical conductivity and maximum turbidity following the hydrograph peak.

The proposed method estimates the MRT for average flow paths in the catchment area of the karst spring, whereas the costly dye-tracer test can estimate the MRT only between the injection and the emergence points. The proposed method has some superiority over the conventional isotopic methods, too, since it's cheaper, able to determine mean residence times and residence-time distributions from existing hydrologic data and practically more appropriate in karst-water exploitation studies.

\section{ACKNOWLEDGMENTS}

The authors would like to acknowledge the Research Council of Shiraz University for their support. The helpful comments and suggestions of the Editor-in-Chief and three anonymous reviewers are gratefully acknowledged. 


\section{REFERENCES}

Alavi, M., 1994, Tectonics of the Zagros orogenic belt of Iran: New data and interpretations: Tectonophysics, v. 229, p. 211-238. doi: 10.1016/ 0040-1951(94)90030-2.

Alavi, M., 2007, Structures of the Zagros fold-thrust belt in Iran: American Journal of Science, v. 307, p. 1064-1095. doi: 10.2475/ 09.2007.02.

Angelini, P., and Dragoni, W., 1997, The problem of modeling limestone springs: The case of Bagnara (North Apennines, Italy): Groundwater, v. 35 , p. $612-618$. doi: $10.1111 /$ j.1745-6584.1997.tb00126.x.

Atkinson, T.C., 1977, Diffuse flow and conduit flow in limestone terrain in the Mendip Hills, Somerset (Great Britain): Journal of Hydrology, v. 35, p. 93-110. doi: 10.1016/0022-1694(77)90079-8.

Baedke, S.J., and Krothe, N.C., 2001, Derivation of effective hydraulic parameters of a karst aquifer from discharge hydrograph analysis: Water Resources Research, v. 37, p. 13-19. doi: 10.1029/2000WR900247.

Benischke, R., Goldscheider, N., and Smart, C., 2007, Tracer techniques, in Goldscheider, N., and Drew, D., eds., Methods in Karst Hydrogeology: Leiden, Taylor \& Francis, International Contributions to Hydrogeology 26, p. 147-170.

Bethke, C.M., and Johnson, T.M., 2008, Groundwater age and groundwater age dating: Annual Review of Earth and Planetary Sciences, v. 36, p. 121-152. doi, 10.1146/annurev.earth.36.031207.124210.

Bonacci, O., 1993, Karst springs hydrographs as indicators of karst aquifers: Hydrological Science, v. 38, p. 51-62. doi: 10.1080/02626669 309492639.

Castro, M.C., and Goblet, P., 2005, Calculation of ground water ages-A comparative analysis. Groundwater, v. 43, p. 368-380. doi: 10.1111/ j.1745-6584.2005.0046.x.

Desmarais, K., and Rojstaczer, S., 2002, Inferring source waters from measurements of carbonate spring response to storms: Journal of Hydrology, v. 260, p. 118-134. doi: 10.1016/S0022-1694(01)00607-2.

Dewandel, B., Lachassagne, P., Bakalowicz, M., Weng, Ph., and AlMalki, A., 2003, Evaluation of aquifer thickness by analyzing recession hydrographs. Application to the Oman ophiolite hard-rock aquifer: Journal of Hydrology, v. 274, p. 248-269. doi: 10.1016/S00221694(02)00418-3.

Doctor, D.H., 2008, Hydrologic connections and dynamics of water movement in the classical Karst (Kras) aquifer: Evidence from frequent chemical and stable isotope sampling: Acta Carsologica, v. 37 , p. $101-123$.

Doyon, B., and Molson, J.W., 2012, Groundwater age in fractured porous media: Analytical solution for parallel fractures: Advances in Water Resources, v. 37, p. 127-135. doi: 10.1016/j.advwatres.2011.11.008.

Falcon, N.L., 1974, Southern Iran: Zagros Mountains: in Spencer, A.M., ed., Mesozoic Orogenic-Cenozoic Belts: Data for Orogenic Studies: Geological Society, London, Special Publications 4, p. 199-211. doi: 10.1144/GSL.SP.2005.004.01.11.

Fiorillo, F., 2011, Tank-reservoir drainage as a simulation of recession limb of karst spring hydrographs: Hydrogeology Journal, v. 19, p. 1009-1019. doi: 10.1007/s10040-011-0737-y.

Fiorillo, F., 2014, The recession of spring hydrographs, focused on karst aquifers: Water Resources Management, v. 28, p. 1781-1805. doi 10.1007/s11269-014-0597-z.

Ford, D.C., and Williams, P., 2007, Karst Hydrogeology and Geomorphology, West Sussex, John Wiley \& Sons, 562 p.

Goode, D.J., 1996, Direct simulation of groundwater age: Water Resources Research, v. 32, p. 289-296. doi: 10.1029/95WR03401.

Gregor, M., and Malík, P., 2012, Construction of master recession curve using genetic algorithms: Journal of Hydrology and Hydromechanics, v. 60 , p. $3-15$. doi: $10.2478 / \mathrm{v} 10098-012-0001-8$.

James, G.A., and Wynd, J.G., 1965, Stratigraphic nomenclature of Iranian Oil Consortium Agreement area: AAPG Bulletin, v. 49, p. 2182-2245.

Johnson, E.A., and Dils, R.E., 1956, Outline for compiling precipitation, runoff, and ground water data from small watersheds: U.S. Forest Service, Southeastern Forest Experiment Station, Station Paper 068, $41 \mathrm{p}$.

Karami, G., 1993, Relationship of physiochemical characteristics of recharged water with the karstic springs in Gar and Barm-Firooz anticline [M.S. Thesis in Persian]: Shiraz, Shiraz University, 349 p.

Kazemi, G.A., Lehr, J.H., and Perrochet, P., 2006, Groundwater Age: Hoboken, New Jersey, John Wiley \& Sons, 325 p.
Lalbat, F., Blavoux, B., and Banton, O., 2007, Description of a simple hydrochemical indicator to estimate groundwater residence time in carbonate aquifers: Geophysical Research Letters, v. 34, L19403, 5 p. doi: $10.1029 / 2007$ GL031390.

Lamb, R., and Beven, K., 1997, Using interactive recession curve analysis to specify a general catchment storage model: Hydrology and Earth System Sciences, v. 1, p. 101-113. doi: 10.5194/hess-1-101-1997.

Langbein, W.B., 1938, Some channel-storage studies and their application to the determination of infiltration: Eos, Transactions American Geophysical Union, v. 19, p. 435-447. doi: 10.1029/TR019i001p00435.

Malík, P., and Vojtková, S., 2012, Use of recession-curve analysis for estimation of karstification degree and its application in assessing overflow/underflow conditions in closely spaced karstic springs: Environmental Earth Sciences, v. 65, p. 2245-2257. doi: 10.1007/ s12665-012-1596-0.

Maloszewski, P., 1994, Mathematical Modelling of Tracer Experiments in Fissured Aquifers, Freiburg, Freibeurger Schriften zur Hydologie, $107 \mathrm{p}$.

Mangin, A., 1975, Contribution à l'étude hydrodynamique des aquifères karstiques [PhD dissertation]: Dijon, Université de Dijon.

Milanovic, P., 1976, Water regime in deep karst: Case study of Ombla Spring drainage area: in Yevjevich, V.M., ed., Karst Hydrology and Water Resources: Proceedings of the U.S.-Yugoslavian Symposium, Dubrovnik, June 2-7, 1975, v. 1, Highlands Ranch, Colorado, Water Resources Publications, p. 165-186.

Nathan. R.J., and McMAhON, T.A., 1990, Evaluation of automated techniques for base flow and recession analysis: Water Resources Research, v. 26, p. 1465-1473. doi: 10.1029/WR026i007p01465.

Pezeshkpour, P., 1991, Hydrogeological and hydrochemical evaluation of Kuh-e Gar and Barm-Firooz springs [M.S. Thesis in Persian], Shiraz, Shiraz University, $282 \mathrm{p}$.

Phillips, P.C.B., and Durlauf, S.N., 1986, Multiple time series regression with integrated processes: The Review of Economic Studies, v. 53, p. 473-495. doi: $10.2307 / 2297602$.

Posavec, K., Bačani, A., and Nakić, Z., 2006, A visual basic spreadsheet macro for recession curve analysis: Groundwater, v. 44, p. 764-767. doi: 10.1111/j.1745-6584.2006.00226.x.

Posavec, K., Parlov, J., and Nakić, Z., 2010, Fully automated objectivebased method for master recession curve separation: Groundwater, v. 48, p. 598-603. doi: 10.1111/j.1745-6584.2009.00669.x.

Raeisi, E., 2008, Ground-water storage calculation in karst aquifers with alluvium or no-flow boundaries: Journal of Cave and Karst Studies, v. 70 , p. $62-70$.

Raeisi, E., 2010, Case Study: Sheshpeer Spring, Iran, in Kresic, N., and Stevanovic, Z., eds., Groundwater Hydrology of Springs: Engineering, Theory, Management and Sustainability, Burlington, Butterworth-Heinemann, p. 516-525.

Raeisi, E., and Karami, G., 1996, The governing factors of the physicochemical characteristics of Sheshpeer karst springs, Iran: Carbonates and Evaporites, v. 11, p. 162-168. doi: 10.1007/BF03 175634.

Raeisi, E., and Karami, G., 1997, Hydrochemographs of Berghan karst spring as indicators of aquifer characteristics: Journal of Cave and Karst Studies, v. 59, p. 112-118.

Raeisi, E., and Kowsar, N., 1997, Development of Shapour Cave, Southern Iran: Cave and Karst Science, v. 24, p. 27-34.

Raeisi, E., Pezeshkpour, P., and Moor, F., 1993, Characteristics of karst aquifers as indicated by temporal changes of the spring's physicochemical properties: Iranian Journal of Science and Technology, v. 17 , p. $17-28$.

Raeisi, E., Zare, M., and Eftekhari, A., 1999, Application of dye tracing for determining characteristics of Sheshpeer karst spring: Theoretical and Applied Karstology, v. 11-12, p. 109-118.

Rutledge, A.T., 1998, Computer programs for describing the recession of ground-water discharge and for estimating mean ground-water recharge and discharge from streamflow records-Update, USGS Water-Resources Investigations Report 98-4148, 43 p.

Snyder, F.F., 1939, A concept of runoff-phenomena: Eos, Transactions American Geophysical Union, v. 20, p. 725-738. doi: 10.1029/TR020 i004p00725.

Stöcklin, J., and Setudehnia, A., 1971, Stratigraphic lexicon of Iran: Part 1, Central, North, and East Iran, Geology Survey of Iran, report 18, $370 \mathrm{p}$. 
Sujono, J., Shikasho, S., and Hiramatsu, K., 2004, A comparison of techniques for hydrograph recession analysis: Hydrological Processes, v. 18, p. 403-413. doi: 10.1002/hyp.1247.

Toebes, C., and Strang, D.D., 1964, On recession curves: Journal of Hydrology (New Zealand), v. 3, no. 2, p. 2-14.

Vitvar, T., Burns, D.A., Lawrence, G.B., McDonnell, J.J., and Wolock, D.M., 2002, Estimation of baseflow residence times in watersheds from the runoff hydrograph recession: Method and application in the
Neversink watershed, Catskill Mountains, New York: Hydrological Processes, v. 16, p. 1871-1877. doi: 10.1002/hyp.5027.

White, W.B., 1988, Geomorphology and Hydrology of Karst Terrains, New York, Oxford University Press, 464 p.

Worthington, S.R.H., 2007, Groundwater residence times in unconfined carbonate aquifers: Journal of Cave and Karst Studies, v. 69, p. $94-102$. 